\title{
The effect of growth rate and haemin on the virulence and proteolytic activity of Porphyromonas gingivalis W50
}

\author{
Philip D. Marsh, Ann S. McDermid, Ailsa S. McKee \\ and Arthur Baskerville
}

Author for correspondence: Philip D. Marsh. Tel: +44980 612287. Fax: +44980612731.

Pathology Division, PHLS Centre for Applied Microbiology and Research, Porton Down, Salisbury SP4 OJG, UK

\begin{abstract}
Porphyromonas gingivalis strain W50 was grown under haemin-limitation and haemin-excess conditions in a chemostat at pH 7.5. The maximum specific growth rate $\left(\mu_{\max }\right)$ was determined at both haemin concentrations $\left(\mu_{\max }=\right.$ $0.236 \pm 0.052$ and $0.271 \pm 0.039 \mathrm{~h}^{-1}$, respectively). This enabled dilution rates to be adjusted so that the virulence and enzyme activity of haemin-limited and haemin-replete cells could be compared at identical relative growth rates $\left(\mu_{\text {ref }}\right)$ of $0.25,0.50$ and 0.75 of their respective $\mu_{\text {max }}$. The data showed that the fastest growing cells were significantly more virulent than those grown more slowly, irrespective of haemin concentration. However, at each growth rate tested, cells grown under haemin-excess conditions were always more virulent than haemin-limited cells. Trypsin-like enzyme activity of whole cultures was also greater at each growth rate under haemin-excess conditions while, conversely, collagenolytic activity was generally higher in haemin-limited cultures. Thus, although growth rate had an effect on the virulence and enzyme activity of $P$. gingivalis, the availability of haemin for growth was the most significant factor.
\end{abstract}

Keywords: Porphyromonas gingivalis, growth rate, haemin, virulence, proteolytic activity

\section{INTRODUCTION}

Porphyromonas (formerly Bacteroides) gingivalis is an obligately anaerobic, Gram-negative bacillus that has been implicated in the pathogenesis of advanced periodontal disease in humans (Mayrand \& Holt, 1988). This species is also highly proteolytic and collagenolytic, and is virulent in experimental animal models, causing spreading, inflammatory infections when mono-infected in rodents (van Steenbergen et al., 1982).

P. gingivalis requires haemin for growth (Gibbons \& MacDonald, 1960). It probably satisfies this requirement in vivo by degrading haem-containing and haemcomplexing host proteins such as haptoglobin, haemopexin and albumin (Beaven et al., 1974; Carlsson et al., 1984), or haemoglobin derived from lysed red blood cells in the gingival crevice (Mukherjee, 1985). At times, this species may be growing in the host under haemin limitation since outer-membrane proteins, expressed only by $P$. gingivalis when grown in vitro under haemin limitation, were recognized by sera from patients with severe progressive periodontal disease (Papaioannou et al., 1991). At other times, there may be an excess of this essential cofactor during periods of bleeding during disease activity (Mukherjee, 1985).

In an earlier study, cells of $P$. gingivalis that were grown at a fixed growth rate under haemin limitation were found to be less virulent than cells grown at the same growth rate under haemin excess (McKee et al., 1986). The explanation for this was proposed to be due, in part, to the production of lower levels of a trypsin-like protease under haemin limitation (Marsh et al., 1988), which is considered an important virulence factor for this organism (Slots \& Genco, 1984). Subsequently, however, it was reported that changes in growth rate affected the production of hydrolytic enzymes by $P$. gingivalis (Minhas \& Greenman, 1989). These authors argued that as we had not necessarily compared cells grown at the same proportion of their maximum growth rate (i.e. at the same relative growth rate, $\mu_{\text {rel }}$; Evans, 1976; Tempest, 1976), the difference in virulence we had observed could be due to a growth-rate effect rather than a haemin-effect on hydrolytic enzyme activity. Consequently, we have compared the virulence 
of $P$. gingivalis grown under both haemin limitation and haemin excess at the same relative growth rates.

\section{METHODS}

Bacterial strains and growth conditions. Porphyromonas gingivalis strain W50 was grown in an LH 500 series II chemostat with a $500 \mathrm{ml}$ working volume, at $37^{\circ} \mathrm{C}, \mathrm{pH} 7 \cdot 5 \pm 0 \cdot 2$, in an atmosphere of $5 \% \mathrm{CO}_{2} / 95 \% \mathrm{~N}_{2}(\mathrm{v} / \mathrm{v})$. The medium was $\mathrm{BM}$ (Shah et al., 1976), modified as described previously (McKee et al., 1986) to give conditions of haemin limitation $\left(0.05 \mathrm{mg} \mathrm{l}^{-1}\right)$ or haemin excess $\left(2.5 \mathrm{~g} \mathrm{l}^{-1}\right)$. The amount of haemin needed to be added to BM in order to achieve haemin limitation was lower than that reported in our previous studies (McKee et al., 1986; Marsh et al., 1988). This was probably due to higher levels of endogenous haemin in the particular batches of media. Peptides were presumed to be the limiting nutrients during growth under haemin excess (McKee et al., 1986). The maximum specific growth rate was determined under haemin limitation and haemin excess conditions by the wash-out method of Tempest (1970). The dilution rate used for wash-out was $0.5 \mathrm{~h}^{-1}$. For subsequent experiments, the dilution rate was adjusted to grow the organism under haemin limitation or haemin excess at the same relative growth rates $\left(\mu_{\mathrm{rel}}=\mu / \mu_{\max }\right.$; Evans, 1976; Tempest, 1976) of $0.25,0.50$ and 0.75 of their respective $\mu_{\max }$. The cell yields were determined by viable counts on horse blood agar (McKee et al., 1986) during steady-state growth at each relative growth rate. Chemostats were set up fresh for each growth rate; ten pot volume changes of medium were allowed to elapse before a culture was considered to have reached a steady-state.

Virulence test. The virulence of cells grown in the chemostat under haemin limitation and haemin excess at the same relative growth rate was compared in mice as described previously (McKee et al., 1986). Briefly, cells taken directly from the chemostat were concentrated by centrifugation $(10000 \mathrm{~g}$ for $10 \mathrm{~min}$ ) and suspended in fresh BM medium. The number of viable cells present was determined by plating decimal dilutions of this concentrated fraction on horse blood agar plates, and performing colony counts after incubation for $14 \mathrm{~d}$ at $37^{\circ} \mathrm{C}$ in an atmosphere of $10 \% \mathrm{CO}_{2} / 10 \% \mathrm{H}_{2} / 80 \% \mathrm{~N}_{2}$ (v/v). Female Porton strain albino mice were anaesthetized with ether and injected subcutaneously with $0 \cdot 1 \mathrm{ml}$ of each bacterial suspension. Deaths were recorded daily for up to $14 \mathrm{~d}$ after infection; surviving and moribund animals were killed with ether at the end of the study.

Enzyme assays. At each steady-state, cultures taken on different days directly from the chemostat were tested for trypsin-like protease activity (EC 3.4.21.4) and for the breakdown of collagen. Trypsin-like activity was determined in a recording spectrophotometer from the rate of hydrolysis of $1.0 \mathrm{mM} \mathrm{N-} \alpha$ benzoyl-L-arginine- $p$-nitroanilide (BAPNA, Sigma) at $405 \mathrm{~nm}$ following the addition of $0.1 \mathrm{ml}$ of culture. Substrate was dissolved daily in $0.05 \mathrm{M}$ phosphate buffer, $\mathrm{pH} 7.5$. One unit of activity (U) caused a change in absorbance of $0.001 \mathrm{~min}^{-1}$; specific activity was expressed as $U$ per $10^{8}$ viable cells.

The assay for collagen breakdown was based on that of Mandl et al. (1953), in which helical regions of the molecule are degraded liberating peptides which are estimated spectrophotometrically as leucine. Culture samples $(0 \cdot 1 \mathrm{ml})$ were incubated anaerobically for $18 \mathrm{~h}$ with $25 \mathrm{mg}$ of type 1 insoluble collagen from bovine achilles tendon (Sigma) that had previously been pre-treated with pepsin to remove contaminating proteins and denatured collagen (McDermid et al., 1988). The collagen was suspended in $5 \mathrm{ml} 0.05 \mathrm{M}$ phosphate buffer, $\mathrm{pH} 7.5$. After incubation, duplicate samples $(0.25 \mathrm{ml})$ were mixed with $1 \mathrm{ml}$ of freshly prepared ninhydrin reagent, and heated for $20 \mathrm{~min}$ in a boiling water bath. When the mixture was cool, $5 \mathrm{ml}$ propan-1ol $(\mathrm{BDH}) /$ water $(1: 1, \mathrm{v} / \mathrm{v})$ was added; after $15 \mathrm{~min}$, the absorbance at $600 \mathrm{~nm}$ was measured and compared with that of a leucine standard; standard collagenase from Clostridium bistolyticum (Sigma) was used as a positive control, and heatkilled cells served as a negative control. One unit of activity (U) liberated $1 \mu \mathrm{mol}$ leucine from collagen in $18 \mathrm{~h}$ at $37^{\circ} \mathrm{C}$; specific activity was expressed as $U$ per $10^{8}$ viable cells.

Statistical analysis. In order to analyse the data on the virulence of $P$. gingivalis, the results were pooled and the differences between cells grown under haemin limitation and haemin excess, and among cells grown at different growth rates $\left(\mu_{\text {rel }}\right)$, were compared using the large sample proportions test (Fisher \& van Belle, 1993).

Enzyme data for the haemin-limited/excess conditions and at the three growth rates were compared by two-way analysis of variance using the Statgraphics computer package (STSC Inc., Rockville, MD, USA).

\section{RESULTS}

\section{Growth characteristics of $\boldsymbol{P}$. gingivalis}

The maximum specific growth rates $\left(\mu_{\max }\right)$ under conditions of haemin limitation and haemin excess were $0.236 \pm 0.052(n=5)$ and $0.271 \pm 0.039(n=5) \mathrm{h}^{-1}$, respectively. For subsequent experiments, cells were grown under haemin limitation at dilution rates of $0.06,0.12$ and $0 \cdot 18 \mathrm{~h}^{-1}$, and under haemin excess at dilution rates of $0 \cdot 07$, 0.14 and $0.20 \mathrm{~h}^{-1}$, to give $\mu_{\text {rel }}$ values of $0.25,0.50$ and $0.75 \mu_{\max }$, respectively, for both haemin-limited and haemin-excess conditions.

\section{Virulence of $P$. gingivalis}

At each growth rate tested, cells of $P$. gingivalis that were grown under haemin-excess conditions were more virulent than their haemin-limited counterparts. There was also a growth rate effect, in that cells grown at the fastest rate $\left(0.75 \mu_{\max }\right)$ were more virulent than cells grown under the same haemin concentration at slower rates (Table 1). The most virulent cells were those growing under haemin excess at the fastest growth rate.

Since the range of infective doses were comparable under all growth conditions, it was considered appropriate to pool all the mouse virulence data to enable statistical analysis of the differences observed between cells grown under haemin limitation and haemin excess (irrespective of growth rate), and among cells grown at different relative growth rates (irrespective of haemin concentration). Using the large sample proportions test, cells grown under haemin excess were significantly more virulent in mice than those grown haemin-limited $(z=6.48, P<0.001)$. Cells grown at $0.75 \mu_{\max }$ also caused a significantly greater proportion of deaths than those grown at either 0.50 or $0.25 \mu_{\max }(z=3.83$ and 5.18 , respectively; $P<0.001$ in both cases). The difference in proportions of mice killed by cells grown at 0.25 and $0.50 \mu_{\max }$ was not statistically significant $\quad(z=1 \cdot 33$, $P=0 \cdot 18$ ). 
Table 1. Effect of relative growth rate $\left(\mu_{\text {rel }}\right)$ and haemin concentration on the virulence of $P$. gingivalis

Virulence is expressed as the number of mouse deaths/total number of mice challenged. Statistical analysis of the data is described in the text.

\begin{tabular}{|c|c|c|c|c|}
\hline \multirow[t]{2}{*}{$\mu_{\text {rel }}$} & \multicolumn{2}{|c|}{ Haemin limited } & \multicolumn{2}{|c|}{ Haemin excess } \\
\hline & $\begin{array}{c}\text { Subcutaneous } \\
\text { infective dose } \\
\left(\log _{10} \text { c.f.u. }\right)\end{array}$ & Virulence & $\begin{array}{c}\text { Subcutaneous } \\
\text { infective dose } \\
\left.\text { ( } \log _{10} \text { c.f.u. }\right)\end{array}$ & Virulence \\
\hline $0 \cdot 25$ & $\begin{array}{l}9 \cdot 44 \\
9 \cdot 13\end{array}$ & $\begin{array}{l}0 / 10 \\
1 / 10\end{array}$ & $\begin{array}{l}9 \cdot 40 \\
9 \cdot 11 \\
8 \cdot 75\end{array}$ & $\begin{array}{l}7 / 10 \\
4 / 10 \\
2 / 10\end{array}$ \\
\hline 0.50 & $\begin{array}{r}10 \cdot 49 \\
10 \cdot 19 \\
9 \cdot 89\end{array}$ & $\begin{array}{l}5 / 10 \\
0 / 10 \\
1 / 10\end{array}$ & $\begin{array}{l}9 \cdot 69 \\
9 \cdot 40 \\
9 \cdot 09\end{array}$ & $\begin{array}{l}6 / 10 \\
4 / 10 \\
8 / 10\end{array}$ \\
\hline $0 \cdot 75$ & $\begin{array}{l}9 \cdot 60 \\
9 \cdot 30\end{array}$ & $\begin{array}{l}4 / 10 \\
4 / 10\end{array}$ & $\begin{array}{r}10 \cdot 03 \\
10 \cdot 08 \\
9 \cdot 38\end{array}$ & $\begin{array}{r}10 / 10 \\
10 / 10 \\
9 / 10\end{array}$ \\
\hline
\end{tabular}

Table 2. Effect of relative growth rate $\left(\mu_{\text {rel }}\right)$ on trypsin-like activity and collagenolytic activity of $P$. gingivalis

Activities are expressed as $U$ per $10^{8}$ viable cells \pm SD. Numbers in parentheses represent the number of determinations. Statistical analysis of the data is described in the text.

\begin{tabular}{|cccccc|}
\hline $\boldsymbol{\mu}_{\text {rel }}$ & \multicolumn{2}{c}{ Haemin limitation } & & \multicolumn{2}{c|}{ Haemin excess } \\
\cline { 2 - 3 } & $\begin{array}{c}\text { Trypsin-like } \\
\text { activity }\end{array}$ & $\begin{array}{c}\text { Collagenolytic } \\
\text { activity }\end{array}$ & & $\begin{array}{c}\text { Trypsin-like } \\
\text { activity }\end{array}$ & $\begin{array}{c}\text { Collagenolytic } \\
\text { activity }\end{array}$ \\
\hline 0.25 & $39.0 \pm 4.5(6)$ & $1.1 \pm 0.5(10)$ & & $52.8 \pm 10 \cdot 0(8)$ & $1.5 \pm 1.2(10)$ \\
0.50 & $39.5 \pm 5.9(6)$ & $21.5 \pm 5.3(10)$ & & $48.8 \pm 1.3(5)$ & $3.4 \pm 0.8(10)$ \\
0.75 & $34.2 \pm 15.7(8)$ & $16.3 \pm 7.3(10)$ & & $89.8 \pm 26.8(7)$ & $4.5 \pm 2.9(10)$ \\
\hline
\end{tabular}

\section{Enzyme activities}

The enzyme activities of cultures taken during steadystate growth at each growth rate are listed in Table 2 . No attempt was made to distinguish between cell-bound and extracellular activities. At each growth rate, haeminexcess cultures had greater trypsin-like activity than those grown haemin-limited. Growth rate had no effect on the trypsin-like activity of haemin-limited cultures, whereas the fastest growing culture had the highest trypsin-like activity during growth under haemin excess. In contrast, haemin-limited cultures displayed higher collagenolytic activity at 0.5 and $0.75 \mu_{\max }$.

Two-way analysis of variance (ANOVA) was performed on the enzyme data in order to compare the effects of both growth rate and of haemin concentration. This analysis showed that haemin-excess conditions were associated with significantly higher levels of trypsin-like activity $\left(P \ll 0.001, F_{1,34}=32.50\right)$. Trypsin-like activity also varied significantly with different growth rates $(0.001<$ $\left.P<0.005, F_{2,34}=6.47\right)$. There was also a significant interaction effect between growth rate and haemin concentration $\left(P<0.001, F_{2,34}=10 \cdot 92\right)$. The major source of this effect was the higher trypsin-like levels detected under haemin excess at $\mu_{\text {rel }}=0.75$ (Table 2).

Increased collagenolytic activity was highly significantly associated with haemin-limited conditions $(P \ll 0 \cdot 001$, $\left.F_{1,55}=93 \cdot 85\right)$. Higher growth rates were also significantly associated with greater levels of collagenolytic activity $\left(P \ll 0.001, F_{2,55}=45.67\right)$, with the most significant effect due to the difference between the lowest growth rate $\left(0.25 \mu_{\max }\right)$ and the higher growth rates $\left(0.5\right.$ and $\left.0.75 \mu_{\max }\right)$ under haemin limitation. There was also a significant interactive effect on collagenolytic activity of growth rate and haemin limitation $\left(P \ll 0 \cdot 001, F_{2,55}=30 \cdot 85\right)$.

\section{DISCUSSION}

It is well established that the growth environment can alter the pathogenicity of bacteria (e.g. Smith, 1980; Taylor, 1984). This study confirms and extends previous 
research which showed that the concentration of haemin in the growth environment can affect the virulence of $P$. gingivalis (McKee et al., 1986). In our earlier work it was found that cells grown with an excess of haemin were more virulent than a comparable infective dose of cells grown at the same fixed growth rate under haemin limitation (McKee et al., 1986). Subsequent work by Minhas \& Greenman (1989), however, showed that hydrolytic enzyme production, including the trypsin-like protease, varied with the growth rate of $P$. gingivalis. Since we had compared the virulence of haemin-limited and haemin-excess cells grown at the same fixed growth rate and not at the same relative growth rate, Minhas \& Greer.man (1989) proposed that the difference in virulence we observed might be due to a growth-rate-rather than to a haemin-effect on the physiology of cells. Consequently, in the present study, we compared the virulence and proteolytic activity of $P$. gingivalis grown under haemin limitation and haemin excess at the same physiological pace (i.e. at the same $\mu_{\text {rel }}$ ). Indeed, as predicted by Minhas \& Greenman (1989), a significant growth-rate-effect on virulence was observed, with the fastest growing cells being more virulent than those grown at slower rates, irrespective of the haemin concentration of the medium. At each growth rate tested, however, haemin-excess cells were always more virulent than their haemin-limited counterparts, and the significance of the haemin effect was stronger than that associated with growth rate, confirming the significance of haemin to the pathogenic potential of this organism.

The higher trypsin-like and lower collagenolytic activities of haemin-excess cultures were in agreement with earlier findings obtained during growth at a single, fixed growth rate (Marsh et al., 1988). Although collagen breakdown is important for tissue destruction (McKee et al., 1986), the data from this study and from earlier work suggest that high levels of trypsin-like activity might determine whether infection or disease occurs.

The precise role played by haemin in the virulence of $P$. gingivalis is not understood fully at present. Cultures grown under haemin excess display greater proteolytic (e.g. the trypsin-like protease) activity, and produce higher concentrations of metabolic end-products such as ammonia, propionate and butyrate (McKee et al., 1986; Marsh et al., 1988) that possess cytotoxic activity (Touw et al., 1982). It has also been shown recently, however, that cells (including outer membranes and extracellular vesicles) grown under haemin excess bind more haemin than do their counterparts grown under haemin limitation (Smalley et al., 1991). Thus, the enhanced virulence of cells grown under haemin excess may be due, in part, to their ability to initiate growth in vivo by utilizing cellbound haemin prior to cells being able to acquire peptides and haemin directly from the degradation of haemcontaining host molecules.

In conclusion, this study has demonstrated that both growth rate and haemin concentration can have a significant effect on the virulence and enzyme activity of $P$. gingivalis, although the influence of haemin was stronger. At each growth rate tested, cells grown in an excess of haemin were always more virulent than those grown at a comparable rate under haemin limitation.

\section{ACKNOWLEDGEMENT}

The authors thank Dr D. J. Bradshaw for his help with the statistical analysis of the data.

\section{REFERENCES}

Beaven, G. H., Chen, S.-H., D'Albis, A. \& Gratzer, W. B. (1974). A spectroscopic study of the haemin-human-serum-albumin system. Eur J Biochem 41, 539-546.

Carlsson, J., Hofling, J. F. \& Sundqvist, G. K. (1984). Degradation of albumin, haemopexin, haptoglobin and transferrin by blackpigmented Bacteroides species. J Med Microbiol 18, 39-46.

Evans, C. G. T. (1976). The concept of relative growth rate. In Continuous Culture, vol. 6, Applications and New Fields, pp. 346-348. Edited by A. C. R. Dean, D. C. Ellwood, C. G. T. Evans \& J. Melling. Chichester: Ellis Horwood.

Fisher, L. D. \& van Belle, G. (1993). Biostatistics: A Metbodology for the Health Sciences, pp. 187-191. New York: John Wiley.

Gibbons, R. J. \& MacDonald, J. B. (1960). Hemin and vitamin K compounds as required factors for the cultivation of certain strains of Bacteroides melaninogenicus. J Bacteriol 80, 164-170.

Mandl, I., MacLennan, J. D. \& Howes, E. L. (1953). Isolation and characterisation of proteinase and collagenase from Cl. histolyticum. J Clin Invest 32, 1323-1329.

Marsh, P. D., McKee, A. S. \& McDermid, A. S. (1988). Effect of haemin on enzyme activity and cytotoxin production by Bacteroides gingivalis W50. FEMS Microbiol Lett 55, 87-92.

Mayrand, D. \& Holt, S. C. (1988). Biology of the asaccharolytic black-pigmented Bacteroides species. Microbiol Rev 52, 134-152.

McDermid, A. S., McKee, A. S. \& Marsh, P. D. (1988). Effect of environmental $\mathrm{pH}$ on enzyme activity and growth of Bacteroides gingivalis W50. Infect Immun 56, 1096-1100.

McKee, A. S., McDermid, A. S., Baskerville, A., Dowsett, A. B., Ellwood, D. C. \& Marsh, P. D. (1986). Effect of hemin on the physiology and virulence of Bacteroides gingivalis W50. Infect Immun 52, 349-355.

Minhas, T. \& Greenman, J. (1989). Production of cell-bound and vesicle-associated trypsin-like protease, alkaline phosphatase and $N$-acetyl- $\beta$-glucosaminidase by Bacteroides gingivalis strain W50. $J$ Gen Microbiol 135, 557-564.

Mukherjee, S. (1985). The role of crevicular iron in periodontal disease. J Periodontol 56 (suppl.), 22-27.

Papaioannou, S., Marsh, P. D. \& Ivanyi, L. (1991). The immunogenicity of outer membrane proteins of haemin-depleted Porphyromonas (Bacteroides) gingivalis $\mathrm{W} 50$ in periodontal disease. Oral Microbiol Immunol 6, 327-331.

Shah, H. N., Williams, R. A. D., Bowden, G. H. \& Hardie, J. M. (1976). Comparison of biochemical properties of Bacteroides melaninogenicus from human dental plaque and other sites. J Appl Bacteriol 41, 473-492.

Slots, J. \& Genco, R. J. (1984). Black-pigmented Bacteroides species, Capnocytophaga species, and Actinobacillus actinomycetemcomitans in human periodontal diseases: virulence factors in colonisation, survival, and tissue destruction. J Dent Res 63, 412-421.

Smalley, J. W., Birss, A. J., McKee, A. S. \& Marsh, P. D. (1991). Haemin-restriction influences haemin-binding, haemagglutination 
and protease activity of cells and extracellular membrane vesicles of Porphyromonas gingivalis W50. FEMS Microbiol Lett 90, 63-68.

Smith, H. (1980). The effect of environmental conditions in vivo and in vitro on the determinants of microbial pathogenicity. In The Molecular Basis of Microbial Pathogenicity, pp. 159-172. Edited by H. Smith, J. J. Shekel \& M. J. Turner. Weinheim: Verlag Chemie.

Taylor, P. W. (1984). Growth environment effects on pathogenicity of Gram-negative bacteria. In Continuous Culture, vol. 8, Biotechnology, Medicine and the Environment, pp. 10-21. Edited by A. C. R. Dean, D. C. Ellwood \& C. G. T. Evans. Chichester: Ellis Horwood.

Tempest, D. W. (1970). The continuous cultivation of microorganisms. 1. Theory of the chemostat. Methods Microbiol 2, 259-276.

Tempest, D. W. (1976). The concept of "relative growth rate": its theoretical basis and practical application. In Continuous Culture, vol. 6, Applications and New Fields, pp. 349-352. Edited by A. C. R. Dean, D. C. Ellwood, C. G. T. Evans \& J. Melling. Chichester: Ellis Horwood.

Touw, J. J. A., van Steenbergen, T. J. M. \& de Graaff, J. (1982). Butyrate: a cytotoxin for Vero cells produced by Bacteroides gingivalis and Bacteroides asaccharolyticus. Antonie Leeuwenboek 48, 315-325.

van Steenbergen, T. J. M., Kastelein, P., Touw, J. J. A. \& de Graaff, J. (1982). Virulence of black-pigmented Bacteroides strains from periodontal pockets and other sites in experimentally induced skin lesions in mice. $J$ Periodontal Res 17, 41-49.

Received 2 August 1993; revised 17 October 1993; accepted 17 November 1993. 